\title{
Evaluation of Four Pasture Legumes Species as Forages and Cover Crops in Oil Palm Plantation
}

\author{
Hutasoit $\mathrm{R}^{1}$, Juniar $\mathrm{S}^{1}$, Tarigan $\mathrm{A}^{1}$, Ratih $\mathrm{DH}^{2}$ \\ ${ }^{I}$ Indonesian Goat Research Station, PO Box I Sei Putih, Galang 20585, North Sumatera \\ ${ }^{2}$ Biology Laboratory, Indonesian Soil Research Institute \\ E-mail: h.rijanto@yahoo.com
}

(received 28-07-2017; revised 16-08-2017; accepted 31-08-2017)

\begin{abstract}
ABSTRAK
Hutasoit R, Juniar S, Tarigan A, Ratih DH. 2017. Evaluasi empat spesies legume herba sebagai sumber hijauan dan cover crop pada perkebunan kelapa sawit. JITV 22(3): 124-134. DOI: http://dx.doi.org/10.14334/jitv.v22i3.1801

Tanaman leguminosa adalah jenis pakan yang sangat berkualitas sebagai pakan ternak. Terbatasnya lahan merupakan masalah dalam pengembangannya. Integrasi dengan perkebunan sawit merupakan salah satu potensi dalam pengembangannya. Penelitian bertujuan untuk mengevaluasi produktivitas beberapa tanaman leguminosa (Arachis glabrata, Stylosanthes guianensis, Clitoria ternatea, and Chamaecrista rotundifolia) sebagai sumber pakan dan cover crop. Uji potensi dilakukan di kebun sawit seluas $4608 \mathrm{~m}^{2}$ dalam rancangan acak lengkap dengan empat perlakuan (spesies legum) dan tiga ulangan. Parameter yang diamati antara lain: Produksi legum, rasio daun/batang, komposisi kimiawi legum, konsentrasi N, P dalam tanah, kandungan mikroba dalam tanah, kecernaan legum dan produksi buah sawit. Hasil penelitian menunjukkan produksi legum BK tertinggi $(\mathrm{P}<0,05)$ pada spesies Clitoria ternatea $\left(16,15\right.$ ton $/ \mathrm{ha}^{-1}$ tahun $\left.^{-1}\right)$, Rasio daun/batang tertinggi $(\mathrm{P}<0,05)$ pada Arachis glabrata (2,09). Komposisi kimiawi BK yang dihasilkan tidak berbeda ( $>0,05)$ berkisar antara 33,75-35,75\%, kandungan $\mathrm{BO}$ $(\mathrm{P}<0,05)$ tertinggi dimiliki Clitoria ternatea. Protein kasar sangat bervariasi $(\mathrm{P}<0,05)$ tertinggi pada Clitoria ternatea $17,84 \%$. kandungan NDF tidak berbeda $(\mathrm{P}>0,05)$. Kandungan ADF paling rendah $(\mathrm{P}<0,05)$ pada Chamaecrista rotundifolia. Kandungan $\mathrm{N}$ pada tanah awal kegiatan relatif sama (rata-rata $0.10 \%)$, namun pada akhir kegiatan meningkat $(\mathrm{P}<0,05)$ tertinggi $0,16 \%$ pada perlakuan Stylosanthes guianensis. Populasi bakteri penambat N tertinggi 1,76 x $10^{9}$ dan bakteri pelarut fosfat $9,8 \times 10^{5}$ terdapat pada perlakuan Clitoria ternatea. Produksi buah kelapa sawit relatif sama $(\mathrm{P}>0,05)$ berkisar antara 16,52-19,21 ton ha ${ }^{-1} \operatorname{tahun}^{-1}$. Disimpulkan bahwa jenis Clitoria ternatea merupakan tanaman leguminosa yang paling baik untuk digunakan sebagai pakan ternak dan cover crop pada tanaman kelapa sawit.
\end{abstract}

Kata Kunci: Leguminosa, Cover Crop, Tanaman Pakan, Kelapa Sawit

\section{ABSTRACT}

Hutasoit R, Juniar S, Tarigan A, Ratih DH. 2017. Evaluation of four pasture legumes species as forages and cover crops in oil palm plantation. JITV 22(3): 124-134. DOI: http://dx.doi.org/10.14334/jitv.v22i3.1801

Pasture legumes is a very high quality of forage. The limited land is the problem of its development. Integration with oil palm plantations is one of the potentials for its development. This study was aimed to investigate the productivity of several legumes (Arachis glabrata, Stylosanthes guianensis, Clitoria ternatea, and Chamaecrista rotundifolia) as forages and cover crop. The potential tests were conducted in oil palm area of $4608 \mathrm{~m}^{2}$, in a complete block design with four treatments (legume species) and three replications. Parameters observed were: Legum production, leaf/stem ratio, chemical composition of legume, concentration of N, P in the soil, microbes in the soil, leguminous digestibility and palm fruit production. Results showed that the highest legume production $(\mathrm{DM})$ was $(\mathrm{P}<0.05)$ in the species of Clitoria ternatea $\left(16.15\right.$ tons $\left.^{-1} \mathrm{year}^{-1}\right)$, the highest leaf/stem ratio $(\mathrm{P}<0.05)$ was in the Arachis glabrata (2.09). The chemical composition $(\mathrm{DM})$ did not differ $(\mathrm{P}>0.05)$ ranged from 33.75 to $35.75 \%$, the organic matter $(\mathrm{OM})$ varied greatly $(\mathrm{P}<0.05)$ the highets was in Clitoria ternatea. The highest Crude protein $(\mathrm{P}<0.05)$ was in Clitoria ternatea $17.84 \%$. NDF concentrations did not differ $(\mathrm{P}>0.05)$. The lowest ADF concentration $(\mathrm{P}<0.05)$ was in Chamaecrista rotundifolia. The concentration of $\mathrm{N}$ in the soil indicated that early year of activity was similar (average $0.10 \%)$, at the end of activity increased $(\mathrm{P}<0.05)$ in treatment Stylosanthes guianensis $(0.16 \%)$. The highest population of $\mathrm{N}$-fixation bacteria of $1.76 \times 10^{9}$ and phosphate solvent of $9.8 \times 10^{5}$ were in the treatment of Clitoria ternatea. Production of fresh fruit bunches of the palm was relatively similar $(\mathrm{P}>0.05)$ ranged from 16.52-19.21 tons ha $^{-1} \mathrm{year}^{-1}$. It is concluded that Clitoria ternatea is the best species of legume tested as forage and cover crop in oil palm plantations.

Key Words: Legume, Forage, Oil Palm

\section{INTRODUCTION}

An increasing livestock, particularly ruminants population should be followed by the availability of feeds, however in Indonesia land availability for forage crop is limited. This condition is also occurred in many countries (Jalaludin 1997; Harahap et al. 2017) which caused by increasing human population forced 
conversion of pasture land for housing or industrial purpose (Mapiye et al. 2007). Alternative area for planting forage crop should be explored, this including land area under plantation including oil palm, rubber, and coffee plantation. Integration of oil palm plantation with forage crop such as herbaceous legume as cover crop is an option as feed source for ruminants.

Previous research has reported the benefits of legume cover crops used to increase soil fertility (Zhou et al. 2012; Gomes et al. 2009; Mazzoncini et al. 2011) and to conserve land conservation (Plieninger \& Gaertner 2011). However, information on double function of cover crop to increase soil fertility and as feed source is limited. Previous study reported that herbaceous legume in ruminant feeding supplied rapidly degradable protein for microbial protein synthesis and contribute to the pool of amino acids available for the synthesis of milk protein and retention in the body tissue (Ramos-Morales et al. 2010). Juma et al. (2006) reported that Clitoria, Mucuna, and Gliricidia can be used as nitrogen supplement to the lactating of Jersey cows. Kemp et al. (2010) feeding chicory (Cichorium intybus), plantain (Plantago lanceolata), red clover (Trifolium pratense) and white clover (Trifolium repens) produced live weight gains in lambs $70 \%$ greater than feeding perennial ryegrass (Lolium perenne) based pastures. Legume as cover crop is known to increase soil organic matter quantity and the soil fertility (Franzluebbers \& Stuedemann 2007; Mohamad et al. 2010) this due to legume symbiosis with Rhizobium which able to fixing nitrogen from the air resulted in reduction the cost of fertilizers such as Urea and TSP up to 40-50\% (Saraswati et al. 1996). The characteristics and morphology of herbaceous legume plants in that they have many root nodules (Oldroyd \& Downie 2008) this make them potential to provide a multitude of benefits to soil conservation and nutrient cycling efficiency while reducing economic risk and increasing profitability.

According to Valbuena et al. (2012); Bell et al. (2014) planting legumes is potential to improve the sustainability and productivity of the smallholder mixed farming systems by providing a high-quality feed which can increased crop and livestock production. Legume forages play an important role in feeding ruminant systems in many tropical and subtropical countries in the world. The information on legume species as cover crop has been reported, the species of herbaceous legumes commonly planted in oil palm plantation are Pueraria phaseloides, Centrosema pubescens, Calopogonium mucunoides, Calopogonium caeruleum and of late Mucuna bracteata (Chiu \& Madsun 2006), but these plants have not been used as animal feed for the production, might be due to its palatability is very low. There are many types of legumes that are familiar as livestock feed. For example, Arachis glabrata, Stylosanthes guianensis, Clitoria ternatea, and Chamaecrista rotundifolia. Each of them has an advantage. According to Constanza et al. (2015) Arachis glabrata have been studied for their potential as a high quality forage plant and the high nutritional value of the forage close to alfalfa. Arachis glabrata as a high quality legume is used for hay in most of the Southern USA. Ghosh \& Bera (2000) reported that the high quality of Arachis glabrata was developed in India as a possible source of legume fodder.

Stylosanthes guianensis has good nutrition, palatable, and high digestibility (Thang et al. 2009; Muamba et al. 2014). It has been the best feed for Hainan black goats because of its high yield and nutritive value (Guodao et al. 1997) Moreover this forage was reported able to increase the performance of west African dwarf sheep (Ogunbode \& Akinlade 2012) and have suitable nutritive values for livestock in tropical regions of China (Li et al. 2014). Phengsavanh \& Ledin (2003) indicated that the diet of goats containing $30-40 \%$ dry matter (DM) of stylo could improve growth rate to $64-70 \mathrm{~g}$ day $^{-1}$.

Clitoria ternatea is commonly known as butterfly pea, potential as high quality forage legume (Abreu et al. 2014). Other than as animal feed, clitoria also has potential as medicinal plants used in various traditional systems such as antidiabetic, antioxidant and antiinflammatory activity (Ponnuswamy \& Wesely Jebasingh Devairrakam 2011; Zingare et al. 2013; Suganya et al. 2014), it is useful in ophthalmopathy, bronchitis, asthma tubercular glands, hemicrania, burning sensation, starngury, helminthiasis, inflammation, vitiated condition of pitta vicerormegaly, and fever (Chauhan et al. 2012).

Chamaecrista rotundifolia had high DM digestibility, potential to provide greater quantities of high quality forage and still have high production in dry season (Larbi et al. 1999) and used as feeding stock during seasonal gap in smallholder mixed farms in the West African derived savanna. The utilization of $C$. rotundifolia hay powder to replace $40 \%$ of wheat bran in the traditional substrate formula for mushroom production increase $76.92 \%$ of the biological efficiency and increase $29.14 \%$ of total yield of mushroom (Weng et al. 2013)

There is few information on those type of legume as a forage and cover crop planted in plantation. Therefore, the purpose of this research was to evaluate the productivity of the four species of legumes as a feed source and cover crop in oil palm plantations, and to evaluate the effect of planting these legumes on soil biophysic condition and fruit bunch production. 


\section{MATERIALS AND METHODS}

\section{Location}

The study was carried out in Asahan District, North Sumatera Province, Indonesia. It is one of the centers of oil palm plantations with a total area of 74.83 .70 ha, and number of cattle was 666.496 , located at $2^{\circ} 03^{\prime}$ $3^{\circ} 26$ 'North latitude, $99^{\circ} 1^{\prime}-100^{\circ} 0^{\prime}$ East Longitude and elevation of $\pm 100 \mathrm{~m}$ above sea level. The mean annual temperature was $250^{\circ} \mathrm{C}$, humidity $70 \%$ with an average rainfall of $1500 \mathrm{~mm} /$ year. This study used 5 years old oil palm owned by smallholder farmers covering an area of $4608 \mathrm{~m}^{2}$, with a light intensity of $50 \%$. The oil palm spacing is $8 \times 8 \mathrm{~m}$. Therefore, there are 72 palm trees on a whole area of research. The type and structure of the soil which is attached in this research area is podsolic with sandy soil structure $52.32 \%$, dust $13.70 \%$, clay $33.98 \%, \mathrm{pH} 5.05, \mathrm{~N}$ Total $0.10 \%$, COrganic $1.01 \%, \mathrm{P}_{2} \mathrm{O}_{5}$-total of $0.53 \mathrm{mg} / 100 \mathrm{~g}, \mathrm{P}-$ Available $4.77 \mathrm{ppm}$. This condition indicates that the soil is very poor (infertile).

\section{Land and seed preparation}

The field was spray to eradicate all green vegetation by using the herbicides Roundup (Glyphosate $360 \mathrm{~g} / \mathrm{l}$ ). Then the soil in the inter-rows was plowed to a depth of approximately $10 \mathrm{~cm}$ to prepare the seedbeds. Four species of legume were: Stylosanthes guianensis, Arachis glabrata, Clitoria ternatea, and Chamaecrista rotundifolia. Seeds were planted into polybags of size $15 \times 25 \mathrm{~cm}$. Polybags were filled with two parts top soil + sand +1 part of compost. Insecticide treatment was given after seedling to avoid ants and another insect.

\section{Experimental design and treatments}

Fourth treatments were arranged in a randomized complete design with three replications. There were 12 plots, each plot size was $16 \times 24 \mathrm{~m}=384 \mathrm{~m}^{2}$. The seedlings were water every day before transferred to the plots area. Polybags were kept in the nursery for eight weeks. For better germination, polybags were kept in $50 \%$ shade for two weeks, then exposed to direct sunlight afterward. All plots were manually weeded and kept without weeds during the experiment. Plots fertilized with $20000 \mathrm{~kg} / \mathrm{ha}$ of goat manure (972 $\mathrm{kg} / \mathrm{plot})$, limestone $1500 \mathrm{~kg} / \mathrm{ha}(72.9 \mathrm{~kg} / \mathrm{plot}), \mathrm{K}_{2} \mathrm{O} 100$ $\mathrm{kg} / \mathrm{ha}(4.86 \mathrm{~kg} / \mathrm{plot})$, and $\mathrm{P}_{2} \mathrm{O}_{5}$ as much $50 \mathrm{~kg} / \mathrm{ha}(2.43$ $\mathrm{kg} / \mathrm{plot})$. Goat manure and the limestone applied before tillage. While $\mathrm{K}_{2} \mathrm{O}$ and $\mathrm{P}_{2} \mathrm{O}_{5}$ were applied to cover crops one month when the forth seedlings were transplanting from nursery to the field. Legumes were grown throughout the oil palm trees with Alleycropping system (about $1 \mathrm{~m}$ ) so that the area spacing between legumes $0.5 \times 0.5 \mathrm{~m}$ area of oil palm were used for the study.

\section{Variable observed}

\section{Dry matter yield}

The biomass of each legume species was harvested from all area in the plot at early flowering (10\%), at 90 days after planted and at 60 days average interval cutting. Observation of harvesting was done of six times. All legumes were harvested at $20 \mathrm{~cm}$ above ground. The data from each plot and harvesting time was calculated to estimate production (ton/ha/year).

\section{Leaf/steam ratio}

The proportion of leaves and stems on legumes taken every harvesting were measured. A $500 \mathrm{~g} / \mathrm{plot}$ samples biomass production of legumes were taken to determine the ratio of leaves and stems. The separation was done, then the weighing was also done in each fraction to calculate leaf and stem ratio. Observation was done every harvest, then all data were averaged at the end of experiment. After separation of leave from stem, the width of leave was measured. Another $500 \mathrm{~g} /$ plot each time harvesting were taken then dried in air forced oven at $65^{\circ} \mathrm{C}$ for $48 \mathrm{~h}$ for dry matter (DM) determination and to analyze nutrient content of legumes. Chemical composition

All samples were bulked according to treatments and replications as a material to determine the chemical content. Samples were ground using hummer mill with a screen $1.0 \mathrm{~mm}$. $\mathrm{N}$ content was analyzed according to AOAC (2005). The neutral detergent fiber (NDF) and acid detergent fiber (ADF) were analyzed according to the method of Van Soest et al. (1991)

\section{Consumption and digestibility}

Feed consumption and dry matter digestibility pasture legumes were performed on 20 cross breed Boer goat $\mathrm{x}$ kacang goat (Boerka) with an average weight of $20 \mathrm{~kg}$ placed in the metabolism cage. Goats were divided into four groups and randomly assigned each group to one of four legume species as a single feed ad libitum in the morning and evening. Drinking water was available at all the times. The adaptation period was allowed for ten days, then followed by measuring feed consumption, total feces excretion and urine secretion performed for five consecutive days. Feed samples were taken daily at feeding and composited and dried at $60^{\circ} \mathrm{C}$ in the oven for three days. Total feces were collected in the morning before feeding. After weighing, $10 \%$ of the feces were subsample and dry in oven at $100^{\circ} \mathrm{C}$ for 24 hours. 


\section{Nitrogen and phosphorus $(P)$ available in the soil}

Analysis of nitrogen and phosphorus content in the soil was done twice, before and after experiment. Before the legume was grown every plot of soil samples collected using soil drill at depth of $20 \mathrm{~cm}$ under the ground. Drilling done in 5 points of each plot at random, then each soil sample of the plots were bulked then taken $500 \mathrm{~g} / \mathrm{plot}$. Drilling was conducted with a distance of $10 \mathrm{~cm}$ from the legume plant. Soil was analysis for Nitrogen $(\mathrm{N})$ content according to AOAC (2005), phosphorus (P) available using extraction method HCL 25\%, according to AOAC (2005).

\section{Bacterial colonies}

Counting of Nitrogen-fixing ( $\mathrm{N}$-fixing) bacteria and Phosphate solubilizing (P-solubilizing) bacteria in this study was done twice at the beginning and the end of the study. Soil samples were taken at depth of $20 \mathrm{~cm}$ around the research area of $100 \mathrm{~g}$ at random (Suganda et al. 2006). Calculates the amount of $\mathrm{N}$-fixing bacteria was counted using plate count method (Somasegaran \& Hoben 1985). While P-solubilizing bacteria counted using pikovskaya media (Saraswati et al. 2007). The colonies of $\mathrm{N}$-fixing bacteria were characterized by pink color, round and convex, whereas P-solubilizing bacteria were characterized by a clear color. Counting the number of colonies was done using equation:

Total population $=$ (number of colonies $) \times(\mathrm{df})$ (CFU) g-1 dry soil dm soil

$\mathrm{df}=$ dilution factor in petri dishes where colonies are counted

$\mathrm{dm}=\quad$ dry matter of soil sample $(\mathrm{g})=$ wet weight $\mathrm{x}$ (1 - water content)

\section{Fresh fruit bunches production}

To determine the production of fresh fruit bunches (FFB) of oil palm was done after legume grown in all areas of research. harvesting done by cutting the bunches of ripe fruit red-orange marked, FFB production was obtained with harvest rotation 14 days using a chisel tool of 10-12.5 cm with the handle of an iron pipe. To facilitate harvesting, the leaf midrib should be cut first, then the fruit bunches of ripe are cut as close to the fruit base maximum of $2 \mathrm{~cm}$. Fruit that falls directly weighed and production recorded in each plot. The data for each harvesting time were collected and calculated for total production in one year.

\section{Statistical analysis}

The study was conducted in a completely randomized design (Gomez \& Gomez 1984) with four treatments (species of legume) and three replications. All data obtained except soil biology were analyzed with a linear model using SAS software (2009). Significant differences among treatment means were tested using Duncan's multiple range test (DMRT) at the 5\% level of. Soil biology ( $\mathrm{N}$ fixing bacteria and $\mathrm{P}$ solubilizing bacteria were analyzed descriptively.

\section{RESULTS AND DISCUSSION}

\section{Plant characteristics and nutrient composition}

\section{Dry mater yield}

Plant characteristics and nutrition composition of four species herbaceous legumes is presented in Table 1. The highest of dry matter yield $(\mathrm{P}<0.05)$ was $C$. ternatea $16.15 \mathrm{t} / \mathrm{ha} / \mathrm{y}$. The high of $C$. ternatea production is most likely due to its rapid propagation ability compared to the three others of species, as indicated by the whole plant was able to cover the soil surface and produced high biomass. Previous study reported that $C$. ternatea production was higher than present study. Ratnawaty \& Fernandes (2009) reported production of $\mathrm{C}$ ternatea was $22 \mathrm{t} \mathrm{ha}^{-1} \mathrm{y}^{-1}$, while Gomez \& Kamani (2003) was $30 \mathrm{tha}^{-1} \mathrm{y}^{-1}$. The high production of the previous study due to $C$. ternatea was planted in the open field, while in the present study this legume were planted in the shaded a under oil palm plantation. The amount of decreased yield in the shaded area is in line with decreasing light intensity from the sun (Fanindi et al. (2010). The lack of sun light resulted in disruption of the metabolism, causing a reduction in the rate photosynthesis and synthesis of carbohydrates. (Alvarenga et al. 2003; Sopandie et al. 2003; Kirschbaum 2011). A tendency of concentrations of chlorophyll and photosynthesis decreased rate with increasing level of shade in plants Croton urucurana Baill. The optimum light intensity differs according to the type of plant (Alvarenga et al. 2003; Sopandie et al. 2003; Kirschbaum 2011). There are plants that grow very well in the shady place, there are also plants that require high light intensity. Plants of this last type are called "sunplants", while the likes shade called "shade plants". 
Table 1. Plant characteristics and nutrition composition of four species of herbaceous legumes grown under oil palm plantation

\begin{tabular}{lccccccc}
\hline \hline \multirow{2}{*}{ Species } & \multirow{2}{*}{$\begin{array}{c}\text { Dry matter yield } \\
(\mathrm{t} / \mathrm{h} / \mathrm{y})\end{array}$} & \multirow{2}{*}{$\begin{array}{c}\text { Leaf of width } \\
(\mathrm{mm})\end{array}$} & $\begin{array}{c}\text { Leaf/stem } \\
\text { ratio }\end{array}$ & & \multicolumn{3}{c}{ Nutrion composition } \\
\cline { 6 - 8 } A. glabrata & $7.2^{\mathrm{b}}$ & $16.50^{\mathrm{b}}$ & $2.09^{\mathrm{a}}$ & $35.31^{\mathrm{a}}$ & $14.57^{\mathrm{b}}$ & $46.30^{\mathrm{a}}$ & $44.03^{\mathrm{a}}$ \\
S. guianensis & $8.16^{\mathrm{b}}$ & $14.03^{\mathrm{b}}$ & $1.19^{\mathrm{b}}$ & $35.75^{\mathrm{a}}$ & $13.85^{\mathrm{b}}$ & $45.06^{\mathrm{a}}$ & $43.94^{\mathrm{a}}$ \\
C. ternatea & $16.15^{\mathrm{a}}$ & $36.37^{\mathrm{a}}$ & $1.53^{\mathrm{b}}$ & $35.06^{\mathrm{a}}$ & $17.84^{\mathrm{a}}$ & $45.84^{\mathrm{a}}$ & $42.00^{\mathrm{a}}$ \\
C. rotundifolia & $2.65^{\mathrm{c}}$ & $19.05^{\mathrm{b}}$ & $1.69^{\mathrm{b}}$ & $33.75^{\mathrm{a}}$ & $14.33^{\mathrm{b}}$ & $43.17^{\mathrm{a}}$ & $39.66^{\mathrm{b}}$ \\
\hline
\end{tabular}

Different superscripts in the same column indicate significant different $(\mathrm{P}<0.05)$

$\mathrm{DM}=$ Dry matter

$\mathrm{CP}=$ Crude protein

$\mathrm{NDF}=$ Neutral detergent fiber

$\mathrm{ADF}=$ Acid detergent fiber

Legume $C$. ternatea indicates more tolerant to shading than three others legumes in this study. Solar intensity was $50 \%$ in oil palm can be accommodated and utilized efficiently by this legume. This is most likely because of the leaf of $C$. ternatea widthest among the three other species. Sunlight acquired by $C$. ternatea sufficient for photosynthesis process, the formation of carbohydrates from $\mathrm{CO}_{2}$ and $\mathrm{H}_{2} \mathrm{O}$ in the green leaves, resulting in the availability of energy in the form of carbohydrates and protein for the growth and development of plants and therefore contributes to the dry matter production (Hatfield et al. 2011).

Leaf/stem ratio. The average of leaf/stem ratio in this research was 1.62. The highest leaf/stem ratio was in A. glabrata (2.09). This ratio was moderate, and almost comparable with Indigofera sp cutting at 60 days was 1.70 reported by Tarigan et al. (2010). Although $S$. guianensis had the lowest ratio (1.19) but still higher than the mulberry plants which was 0.73 (Ginting et al. 2014) Similarly, the lower leaf/stem ratio was also reported on Clitoria (0.94), mucuna (1.0) and lablab (0.58) (Macedo et al. 2015). The high leaf ratio in this study is likely influenced by the shade from oil palm, the shade caused widened the leaves and try to find and accommodate the sunlight, the expansion of leaf area is one of the mechanisms of tolerance on shade to obtain a higher light or the optimization of light reception by the plant. Therefore, widen leaves resulted in the increase proportion of leaf. The higher leaves proportion of forages might an indication that these feed have good quality (Shehu et al. 2001; Gustavsson \& Martinsson 2004) and could increase feed consumption and nutrient intake due to some of the nutrients were higher the leaves than stems.

\section{Nutrition composition}

The nutrition composition fourth species of legumes shows that the average content of dry matter (DM) produced were relatively similar and was not significantly different $(\mathrm{P}>0.05)$ among legume species. Overall, DM content was high ranging between 33.75 to $35.75 \%$, which was higher than DM mulberry plants (16\%) reported by Ginting et al. (2014). Crude protein (CP) obtained ranged from 13.85 to $17.84 \%$ the highest $(\mathrm{P}<0.05) \mathrm{CP}$ content was in $C$. ternatea $(17.84 \%)$. CP content in $C$. ternatea in this study is comparable to the report by Gomez \& Kamani (2003) between 14-20\%, but was higher than previous studies reported by Macedo et al. (2015) which was in range 21.3-22.01\%. The fiber content was relatively moderate, NDF content was between 43.17 to $46.30 \%$ was not significantly different $(\mathrm{P}>0.05)$ among legumes studied. Whereas ADF content was slightly varied in ranged between 39.66 to $44.03 \%$, and was significantly different $(\mathrm{P}<0.05)$ in which $C$. rotundifolia contained the lowest ADF (39.66\%). This was likely due to the softer structure of the plant. These results were similar to the study by Pholsen et al. (2014) 39.46\% ADF. However higher than (study by Clem et al. (1996) with averaged ADF content $36.62 \%$ (leaves 28.85 , and stems $44.39 \%$ ), the lower $\mathrm{ADF}$ content could indicate that the lignin level is low and the fiber content is good, this is often used to calculate digestibility (Van Saun \& Herdt 2013). Although ADF and NDF C. rotundifolia were low in this study, but it digestibility was not significantly different from the three other of legumes (Table 2).

\section{Consumption and digestibility}

Feed consumption and dry matter digestibility of four legumes species on goats are shown in Table 2. Feed consumption of sheep fed on A. glabrata and $S$. guianensis were similar and was significantly higher $(\mathrm{P}<0.05)$ than $C$. ternatea and $C$. rotundifolia . Feed consumption in \%DM/BW of A. glabrata and $S$. guianensis were 3.1 and $3.3 \% \mathrm{DM} /$ body weight respectively. While DM consumption of $C$. ternatea and $C$. rotundifolia was lower (2.6-2.8\% body weight) 
Table 2. Consumption and digestibility of dry matter four species of legumes given ad libitum on goats

\begin{tabular}{lccc}
\hline \hline \multirow{2}{*}{ Species of legumes } & \multicolumn{2}{c}{ Consumption (DM) } & Digestibility (\%) \\
\cline { 2 - 3 } & $\mathrm{g} / \mathrm{d}$ & $\mathrm{g} / \mathrm{kg} \mathrm{BW}$ & $56.44^{\mathrm{a}}$ \\
A. glabrata & $805^{\mathrm{a}}$ & $33.17^{\mathrm{a}}$ & $54.16^{\mathrm{a}}$ \\
S. guianensis & $775^{\mathrm{a}}$ & $31.87^{\mathrm{a}}$ & $61.50^{\mathrm{a}}$ \\
C. ternatea & $611^{\mathrm{b}}$ & $26.87^{\mathrm{b}}$ & $56.16^{\mathrm{a}}$ \\
C. rotundifolia & $654^{\mathrm{b}}$ & $28.02^{\mathrm{b}}$ & \\
\hline
\end{tabular}

Different superscripts in the same column indicate significant differences $(\mathrm{P}<0.05)$

respectively. The high consumption of A. glabrata was probably due to the high proportion of leaves of this legume (Table 1). While $S$. guianensis have smaller leaf size $(14.03 \mathrm{~mm})$, so easy to eat and good preference for goat. However, the high consumption of A. glabrata and $S$. guianensis was not followed by high levels of digestibility. DM digestibility was not significantly different among four herbaceous legumes with average of $57.06 \%$. This result is comparable to the study reported by Macedo-Barragán et al. (2011) who observed DM digestibility of C. ternatea was $59.37 \%$, while Juma et al. (2006) observed when Clitoria used as nitrogen supplements to the grass basal Napier diet, they found that diet digestibility was $58.9 \%$.

\section{Soil biophysical condition and fruit bunch production}

Biophysic of soil before and fruit bunch production is presented in Table 3. The average nitrogen $(\mathrm{N})$ concentration in the soil at the beginning of the study was similar $(\mathrm{P}>0.05)$ ranged from $0.9-0.10 \%$. This condition indicates that the concentration of $\mathrm{N}$ contained in these plantation areas is very low. At the end of the study, $\mathrm{N}$ content in the soil increased, the highest increased was in land grown by $S$. guianensis $(0.16 \%)$. The increased of $\mathrm{N}$ content indicates that legumes as cover crop was able to increase $\mathrm{N}$ concentration in the soil. The increase in $\mathrm{N}$ content is caused by the presence of Rhizobium in root nodule which fixed nitrogen from air. The high $\mathrm{N}$ content in soil grown by $S$. guianensis treatment was probably because $S$. guianensis produces more root nodules compared to the other three species. Despite the increase $\mathrm{N}$ in the soil in this study, this concentration has still below the minimum threshold. Hardjowigeno (2003) suggested the normal $\mathrm{N}$ concentration in soil is approximately $0.2-0.3 \%$. The low $\mathrm{N}$ content acquired was likely due to shorter duration of this study (one year). (Carlsson et al. 2009) reported that the significant effects of cover crop on soil condition estimated about 3-4 years to reach a normal level of $\mathrm{N}$ concentration. So it might be still takes another 2 years to observe the increase of $\mathrm{N}$ concentration due to cover crop by legume. The highest increased of $\mathrm{N}$ content in soil due to cover crop was obtained by $S$. guianensis plant $(0.06 \%)$. When it was calculated as economic returns from one hectare of land under oil palm, inter-cropping as well as fodder cultivation $S$. guianensis can be accumulated with $\mathrm{N}$ content $\mathrm{x}$ soil/ha $(2,000,000 \mathrm{~kg})$ equal to $0.06 \% \times 2,000,000=1200 \mathrm{~kg} \mathrm{~N} / \mathrm{ha} /$ year, equivalent to $2667 \mathrm{~kg}$ of urea. By converting the price of 5000 IDR per kg urea, $S$. guianensis as a cover crop has to benefit of $13,335,000 \mathrm{IDR} / \mathrm{ha}^{-1} / \mathrm{yr}^{-1}$. While, the three others have a profit of $6,667,000$ IDR, ( $A$. glabrata), 4445000 IDR $(C$. rotundifolia), and 2,223,000 IDR /ha/year (C. ternatea).

Biochemical test to observe concentration of $\mathrm{P}$ available shows that at the start of the research had an average of $2.92 \mathrm{ppm}$ ranged from 1.51 (A. glabrata) to 5.76 (C. ternatea) (Table 3 ). At the end of the study, the average of P. Available increases to $5.15 \mathrm{ppm}$. The highest increased was in $S$. guianensis (7.75 ppm), this indicates that the microbes have ability to increase of $\mathrm{P}$ in the soil, without affecting legume biomass production. This most likely caused by $S$. guianensis plants is intolerant to shade under oil palm, resulted in smaller leaf size as caused by light received was not maximal for plant biomass to grow. On the other hand, P-available on the treatment $C$. ternatea numerically decreased from 5.76 to $4.09 \mathrm{ppm}$, while phosphatesolubilizing was higher $\left(9.8 \times 10^{5}\right)$ in this plant. This might be associated with the higher of dry matter yield production in $C$. ternatea. The biomass plant harvested of this was quite big (16.15 ton $\mathrm{ha}^{-1} \mathrm{yr}^{-1}$ (Table 2)). The high biomass production of $C$. ternatea as a result of higher population of $\mathrm{P}$ solubilizing bacteria, wich related to availability $\mathrm{P}$ in the soil. Phosphate in the soil directly absorbed by the roots and used for the legume production (Baligar \& Fageria 2007; Karti \& Setiadi 2011). Legume as a cover crop in this study positively increased the $\mathrm{P}$-available in the soil. Type of bacteria that caused P-available increase are Bacillus sp, and Pseudomonas sp, this microbes was detected effectively in dissolving phosphate in the shade of oil palm. Interactions between plants and microorganisms can cause significant effect on increasing the availability of phosphate to $7.75 \mathrm{ppm}$. The activity of 
Table 3. Concentration of Nitrogen, Phosphate, nitrogen fixing bacteria and phosphor solubilizing bacteria population, and fresh fruit bunches production on land grown by four species of herbaceous legumes under oil palm plantation

\begin{tabular}{lccccccc}
\hline \multirow{2}{*}{ Species } & \multicolumn{2}{c}{ N. Content $(\%)$} & \multicolumn{2}{c}{ P. Available $(\mathrm{ppm})$} & \multicolumn{2}{c}{ Bacteria colonies CFU/g } & \multicolumn{2}{c}{$\begin{array}{c}\text { Fresh fruit bunches } \\
\text { (FFB) t/ha }\end{array}$} \\
\cline { 2 - 6 } & Start & End & Start & End & N-fixing & P-solubilizing & $16.52^{\mathrm{a}}$ \\
\hline A. glabrata $_{\text {S. guianensis }}$ & $0.10^{\mathrm{a}}$ & $0.13^{\mathrm{b}}$ & $1.51^{\mathrm{b}}$ & $4.98^{\mathrm{b}}$ & $3.4 \times 10^{6}$ & $9.0 \times 10^{1}$ & $17.52^{\mathrm{a}}$ \\
C. ternatea & $0.10^{\mathrm{a}}$ & $0.16^{\mathrm{a}}$ & $2.53^{\mathrm{b}}$ & $7.75^{\mathrm{a}}$ & $1.28 \times 10^{6}$ & $5.0 \times 10^{2}$ & $17.31^{\mathrm{a}}$ \\
C. rotundifolia & $0.10^{\mathrm{a}}$ & $0.11^{\mathrm{b}}$ & $5.76^{\mathrm{a}}$ & $4.09^{\mathrm{b}}$ & $1.76 \times 10^{9}$ & $9.8 \times 10^{5}$ & $19.21^{\mathrm{a}}$ \\
\hline
\end{tabular}

Different superscripts in the same column indicate significant different $(\mathrm{P}<0.05)$

the microorganisms found in legumes can secrete organic acids such as oxalate, succinate, fumarate, and malate.

Organic acids react with the binder phosphates such as $\mathrm{Al}^{3+}, \mathrm{Fe}^{3+}, \mathrm{Ca}^{2+}$, or $\mathrm{Mg}^{2+}$ to form a stable organic chelate, so can release the phosphate ions from binding. Therefore P supplied from fertilizer can be absorbed by plants (Singh \& Reddy 2011). Phosphate-solubilizing bacteria produce phytohormones such as Indole Acetic Acid (IAA) and Gibberellic Acid (Ga3), as well siderophores which is antagonists against the pathogen (Nenwani et al. 2010; Parani \& Saha 2012), Therefore phosphate-solubilizing bacteria a potential biofertilizer to support plant growth and absorbed phosphate ions, especially $\mathrm{H}_{2} \mathrm{PO}_{4}$ and $-\mathrm{HPO}_{2}$ contained in the soil solution. (Kumalasari \& Setyorini 2008) reported the presence of phosphate-solubilizing bacteria in Calopogonium mucunoides grown in soil post-mine tailings gold gave resulted in the best growth response to this plant. The increase of P. Available was also reported by Agisti et al. (2014) using Legume Cover Crop (LCC) in the area of the former coal mines give real effect on the increase of C-organic, and $\mathrm{N}$-total content, the soil $\mathrm{pH}$, and increased $\mathrm{P}$ available from 24$25 \mathrm{ppm}$ to 55-64 ppm.

Population of $\mathrm{N}$-fixing bacteria was highest in $C$. ternatea $\left(1.7 \times 10^{9} \mathrm{cfu} / \mathrm{g}\right)$ followed by $C$. rotundifolia $\left(5.0 \times 10^{8} \mathrm{cfu} / \mathrm{g}\right)$ and (Table 3). According to Indonesian Government regulation (Permentan 2011), the standard number of $\mathrm{N}$-fixing bacteria in the soil is $\geq 10^{7} \mathrm{CFU} / \mathrm{g}$. This indicates that cover crop C. ternatea and $C$. rotundifolia was able to produce good quality soil that meet standard by Permentan (2011) for growing crop. Purwaningsih (2009) reported that arable land contains more than 100 million microbes per gram of soil, while Alexander (1977), reported the population of bacteria was $10^{9}$ cell/g soil.

The high population of bacteria in $C$. rotundifolia and $C$. ternatea was due to environmental such as temperature, humidity, and light under oil palm growth by these two legumes species was suitable for the growth of microbes (Widawati 2006). Suitable environement condition can support the survive of soil microbial which in turn improve soil fertility through fixing nitrogen from the air then convert it into a compound that can be absorbed by the plants (Agisti et al. 2014). Soil biology in present study shows that the high $\mathrm{N}$-fixing bacteria in legume $C$. rotundifolia and $C$. ternatea planted in the area under oil palm plantation has potential as biofertilizer to support plant growth. This is caused that organic material such as leaf and flower produced by $C$. rotundifolia and $C$. ternatea that fall to the ground in large quantities, so that sufficient to support the growth and development microbes. On the other hand, N-fixing microbial populations in $A$. glabrata and $S$. guianensis plants were lower $\left(3.4 \times 10^{6}\right.$ $\mathrm{cfu} / \mathrm{g})$ and $\left(1.28 \times 10^{6} \mathrm{cfu} / \mathrm{g}\right)$ respectively. The low organic material contained in the media around the roots of both legume species caused the low growth of microbes. Rhizobium bacteria living in the rhizosphere must compete with other soil microbes to obtain exudates and specific compounds may affect the growth of microorganisms adapt to environmental conditions (Nikiyan et al. 2010).

The population of phosphate-solubilizing bacteria (PSB) in the present study was varied (Table 3). Numericaly, the highest population was in treatment $C$. ternatea $\left(9.8 \times 10^{5} \mathrm{CFU} / \mathrm{g}\right)$, this result was in line with the high dry matter yield obtained in C. ternatea (Table 1 ). The high population $C$. ternatea could be due to the ability of phosphate solubilizing bacteria growing in this legume to provide $\mathrm{P}$ to be absorbed by the plant. Bacteria Pseudomonas, Bacillus, Escherichia, Actinomycetes a group of soil microorganisms are capable of dissolving phosphorus $(\mathrm{P})$ which is fixed in the soil and turn it into a form that is available can be absorbed by plants that affect to the biomass production (Khen 2006). According to Jalaludin et al. (2010) these microbes secrete of kinds organic acids such as formic acid, acetic, propionic, lactic, glycolic, fumaric, and succinic. They chelate the ions with the cation $\mathrm{Al}, \mathrm{Fe}$ or $\mathrm{Ca}$ binding $\mathrm{P}$, so that the ion $\mathrm{H}_{2} \mathrm{PO}_{4}{ }^{-}$can be released from the bond becomes available for plants to be absorbed. 
The PSB populations is relatively low in plans $A$. glabrata, S. guianensis, and C. rotudifolia $\left(9.0 \times 10^{1}\right.$, $5.0 \times 10^{2}$, and $\left.1.6 \times 10^{3} \mathrm{cfu} / \mathrm{g}\right)$ respectively this population affect to the effectiveness of phosphate dissolution in the soil subsequently effect on production dried matter yield of legumes (Table 1). This result of the present study indicates that there were differences in the mechanisms by P-bound on a wide variety of species of legume. Therefore the low PSB population around the roots in all three legume species caused low biomass production. Schipanski et al. (2014) stated that the low population of bacteria is most likely caused by environmental conditions which are less than optimal caused by the lack of organic material around the roots of legumes that affect the activity of living microorganisms. Therefore the low PSB population around the roots in all three plant species mentioned above.

\section{Fresh fruit brunches (FFB) production}

The average of FFB production obtained in this study (Table 3) was $17.64 \mathrm{tha}^{-1} \mathrm{yr}^{-1}$, ranged from 16.52$19.21 \mathrm{t} \mathrm{ha}^{-1} \mathrm{yr}^{-1}$. There was no significant difference FFB production in each treatment. While Hafif et al. (2014) reported lower FFB production at oil palm age 4.5 year in Tuba Distrik with cover crop grown under oil palm plantation was $15.36 \mathrm{t} \mathrm{ha}^{-1} \mathrm{yr}^{-1}$, whereas production without cover crop was $12.36 \mathrm{tha}^{-1} \mathrm{yr}^{-1}$.

Some legumes in this study showed no effect on fruit bunches production. This is probably the absence of any apparent effect of some legume crop species since the time observations is only one year. The Possibility N-fixing (Rhizobium) and phosphate solvent bacteria secreting coenzymes, nucleic acids, and other metabolic compounds have not spread to all roots, and exploited by of oil palm (Samedani et al. 2014). Numerically $C$. rotundifolia plots began to show higher FFB production yield than the three others of treatments. This is closely related to the high $\mathrm{N}$-fixing bacteria population on $C$. rotundifolia plants (Table 3 ) can bind free nitrogen from the air and convert it into a compound began absorbed by plants, indicated in the treatment of metabolic compounds ranging role of soil biology to increase FFB production. Although FFB production in the treatment of $C$. ternatea is lower than C. rotundifolia, but the legume biomass produced was higher (Table 1). This is most likely nutrients of $\mathrm{N}$ and $\mathrm{P}$ produced by legume crops more absorbed for legume biomass compared to FFB production.

\section{CONCLUSION}

Clitoria ternatea is potential legume as fodder due to better nutrient quality and potential as cover crop in oil palm plantation as indicated by highest biomass production due to higher number of bacteria $\mathrm{N}$-fixing and phosphate-solubilizing bacteria in the soil of Clitoria ternatea increase available $\mathrm{N}$ and $\mathrm{P}$.

\section{REFERENCES}

Abreu MLC, Vieira RAM, Rocha NS, Araujo RP, Glória LS, Fernandes AM, De Lacerda PD, Gesualdi A. 2014. Clitoria ternatea $\mathrm{L}$. as a potential high quality forage legume. Asian-Australas J Anim Sci. 27:169-178.

Agisti A, Alami NH, Hidayati TN. 2014. Isolasi dan dentifiasi bakteri penambat nitrogen non simbiotik pada lahan restorasi dengan metode Legume Cover Crop (LCC) di Daerah Pasirian Lumajang Jawa Timur. J Sains Seni Pomits. 3:2301-9271.

Alexander M. 1977. Soil microbiology. 2nd ed. New York (USA): John Wiley and Sons Inc. p. 472.

Alvarenga AA de, Castro EM de, Lima Junior É de C, Magalhães MM. 2003. Effects of different light levels on the initial growth and photosynthesis of Croton urucurana Baill. in southeastern Brazil. Rev Árvore. 27:53-57.

[AOAC] Association of Official Analytical Chemists. 2005. Official methods of analysis of AOAC international. 18th ed. Gathersburg, MD (USA): Association of Official Analytical Chemists.

Baligar VC, Fageria NK. 2007. Agronomy and physiology of tropical cover crops. J Plant Nutr. 30:1287-1339.

Bell LW, Moore AD, Kirkegaard JA. 2014. Evolution in croplivestock integration systems that improve farm productivity and environmental performance in Australia. Eur J Agron. 57:10-20.

Carlsson G, Palmborg C, Jumpponen A, Scherer-Lorenzen M, Högberg P, Huss-Danell K. 2009. $\mathrm{N}_{2}$ fixation in three perennial Trifolium species in experimental grasslands of varied plant species richness and composition. Plant Ecol. 205:87-104.

Chauhan N, Rajvaidhya S, Dubey BK. 2012. Pharmacognostical, phytochemical and pharmacological review on Clitoria ternatea for antiasthmatic activity. Int J Pharm Sci Res. 3:398-404.

Chiu SB, Madsun B. 2006. Mucuna bracteata - biomass, litter and nutrient production. Planter. 82:247-254.

Clem RL, Compton JF, Cook BG, English BH, Ford G, Gilbert M, Hilder TB, Hopkinson JM, James TA, Middleton CH, et al. 1996. Interim Final Report on Project DAQ. 083 Backup Legumes for Sty los Technical Collaborators :

Constanza K, Tallury S, Whaley J, Sanders T, Dean L. 2015. Chemical composition of the essential oils from leaves of edible (Arachis hypogaea L.) and Perennial (Arachis glabrata Benth.) peanut plants. J Essent Oil Bear Plants. 18:605-612.

Fanindi A, Prawiradiputra BR, Abdullah L. 2010. Pengaruh intensitas cahaya terhadap produksi hijauan dan benih 
Kalopo (Calopogonium mucunoides). JITV. 15:205214.

Franzluebbers AJ, Stuedemann JA. 2007. Crop and cattle responses to tillage systems for integrated croplivestock production in the Southern Piedmont, USA. Renew Agric Food Syst. 22:168-180.

Ghosh PK, Bera SK. 2000. Wild Arachis species: a possible source of legume fodder in India. Int Arachis Newsl. 20:88-89.

Ginting SP, Tarigan A, Hutasoit R, Yulistiani D. 2014 Preferensi, kecernaan dan karakteristik fermentasi rumen beberapa spesies murbei pada kambing. JITV. 19:176-183.

Gomes J, Bayer C, de Souza Costa F, de Cássia Piccolo M, Zanatta JA, Vieira FCB, Six J. 2009. Soil nitrous oxide emissions in long-term cover crops-based rotations under subtropical climate. Soil Tillage Res. 106:36-44.

Gomez KA, Gomez AA. 1984. Statistical procedures for agricultural research. New York (USA): John Wiley Sons Inc. p. 206-212.

Gomez SM, Kamani A. 2003. Butterfly Pea (Clitoria ternatea): A nutritive multipurpose forage legume for the Tropics- An Overview. Pak J Nutr. 2:374-379.

Guodao L, Phaikaew C, Stur WW. 1997. Status of Stylosanthes development in other countries. II. Stylosanthes development and utilisation in China and south-east Asia. Trop Grassl. 31:460-466.

Gustavsson AM, Martinsson K. 2004. Seasonal variation in biochemical composition of cell walls, digestibility, morphology, growth and phenology in timothy. Eur $\mathrm{J}$ Agron. 20:293-312.

Hafif B, Ernawati R, Pujiarti Y. 2014. Peluang peningkatan produktivitas kelapa sawit rakyat di Provinsi Lampung. J Littri. 20: 100-108.

Hardjowigeno S. 2003. Ilmu tanah. Jakarta (Indones): Akademika Pressindo.

Harahap F, Silveira S, Khatiwada D. 2017. Land allocation to meet sectoral goals in Indonesia - An analysis of policy coherence. Land Use Policy. 61:451-465.

Hatfield JL, Boote KJ, Kimball BA, Ziska LH, Izaurralde RC, Ort D, Thomson AM, Wolfe D. 2011. Climate impacts on agriculture: Implications for crop production. Agron J. 103:351-370.

Jalaludin A, Ngim J, Bakar BHJ, Alias Z. 2010. Preliminary findings of potentially resistant goosegrass (Eleusine indica) to glufosinate-ammonium in Malaysia. Weed Biol Manag. 10:256-260.

Jalaludin S. 1997. Integrated animal production in the oil palm plantation. Livest Feed Resour within Integr Farming Syst Second FAO Electron Conf Trop Feed. p. $37-43$.

Juma HK, Abdulrazak SA, Muinga RW, Ambula MK. 2006. Evaluation of Clitoria, Gliricidia and Mucuna as nitrogen supplements to Napier grass basal diet in relation to the performance of lactating Jersey cows. Livest Sci. 103:23-29.

Karti PDMH, Setiadi Y. 2011. Respon pertumbuhan, produksi dan kualitas rumput terhadap penambahan fungi mikoriza arbuskula dan asam humat pada tanah masam dengan aluminium tinggi. JITV. 16:105-112.

Karti PDMH, Kumalasari NR, Setyorini D. 2008. Peranan fungi Mikoriza arbuskula, mikroorganisme pelarut fosfat, rhizobium sp dan asam humik untuk meningkatkan pertumbuhan dan produktivitas legum Calopogonium mucunoides pada tanah latosol dan tailing tambang emas di PT. Aneka Tambang. Pastura. 3:44-47.

Kemp P, Kenyon P, Morris S. 2010. The use of legume and herb forage species to create high performance pastures for sheep and cattle grazing systems. Rev Bras Zootec. 39:169-174.

Khen CV. 2006. Impacts of forest conversion on biodiversity as indicated by moths. Malayan Nat J. 57:383-418.

Kirschbaum MUF. 2011. Does enhanced photosynthesis enhance growth? Lessons learned from $\mathrm{CO} 2$ enrichment studies. Plant Physiol. 155:117-124.

Larbi A, Adekunle IO, Awojide A, Akinlade J. 1999. Identifying Chamaecrista rotundifolia accessions and Centrosema species for bridging seasonal feed gaps in smallholder mixed farms in the West African derived savanna. Trop Grassl. 33:91-97.

Li M, Zi X, Zhou H, Hou G, Cai Y. 2014. Chemical composition and in vitro digestibility of Stylosanthes guianensis varieties. Grassl Sci. 60:125-129.

Macedo-Barragán R, Isela López-Poblete N, Arredondo-Ruiz V, Rodríguez-Ramírez R. 2011. Precision of an equation to estimate dry matter degradability of Clitoria ternatea. Trop Subtrop Agroecosystems. 14:943-947.

Macedo RJ, Arredondo V, Garcia N, Ramirez R, Prado O, Garcia LJ. 2015. Productive performance of three tropical legumes for protein banks in the dry tropics of Colima, Mexico. Trop Grassl-Forrajes Trop. 3:104-111.

Mapiye C, Mwale M, Mupangwa JF, Mugabe PH, Poshiwa X, Chikumba N. 2007. Utilisation of ley legumes as livestock feed in Zimbabwe. Trop Grassl. 41:84-91.

Mazzoncini M, Sapkota TB, Bàrberi P, Antichi D, Risaliti R. 2011. Long-term effect of tillage, nitrogen fertilization and cover crops on soil organic carbon and total nitrogen content. Soil Tillage Res. 114:165-174.

Mohamad RB, Wibawa W, Mohayidin MG, Puteh AB, Juraimi AS, Awang Y, Lassim MBM. 2010. Management of mixed weeds in young oil-palm plantation with selected broad-spectrum herbicides. Pertanika J Trop Agric Sci. 33:193-203.

Muamba IT, Ignatius VN, Mangeye HK, Hornick J-L. 2014. Nutritive value of Adenodolichos rhomboideus leaves compared with Leucaena leucocephala and Stylosanthes guianensis forages in indigenous goats in Lubumbashi 
(DR Congo). Biotechnol Agron Soc Environ. 18:165173.

Nenwani V, Doshi P, Saha T, Rajkumar S. 2010. Isolation and characterization of a fungal isolate for phosphate solubilization and plant growth promoting activity. Yeast. 1:9-14.

Nikiyan H, Vasilchenko A, Deryabin D. 2010. Humiditydependent bacterial cells functional morphometry investigations using atomic force microscope. Int J Microbiol. 2010:704170.

Ogunbode S, Akinlade J. 2012. Effect of Three Species of Stylosanthes on The Performance of West African Dwarf Sheep. Fountain J Nat Appl Sci. 1:36-40.

Oldroyd GED, Downie JA. 2008. Coordinating Nodule Morphogenesis with Rhizobial Infection in Legumes. Annu Rev Plant Biol. 59:519-546.

Parani K, Saha BK. 2012. Prospects of using phosphate solubilizing Pseudomonas as bio fertilizer. Eur J Biol Sci. 4:40-44.

Permentan. 2011. Peraturan Menteri Pertanian Nomor 70/Peraturan Menteri Pertanian Republik Indonesia/SR.140/10/2011 Tentang Pupuk Organik, Pupuk Hayati Dan Pembenah Tanah. Permentan. p. 16.

Phengsavanh P, Ledin I. 2003. Effect of Stylo 184 (Stylosanthes guianensis CIAT 184) and Gamba grass (Andropogon gayanus cv. Kent) in diets for growing goats. Livest Res Rural Dev. 15:1-11.

Pholsen S, Rodchum P, Higgs DEB. 2014. Dry matter yields and quality of forages derived from grass species and organic production methods (Year 11l). Pak J Biol Sci. 17:898-904.

Plieninger T, Gaertner M. 2011. Harnessing degraded lands for biodiversity conservation. J Nat Conserv. 19:18-23.

Ponnuswamy S, Wesely Jebasingh Devairrakam EG. 2011. Comparative study of primary metabolites in different plant parts of Clitoria ternatea Linn. J Chem Pharm Res. 3:614-617.

Purwaningsih S. 2009. Populasi Bakteri Rhizobium di Tanah pada beberapa Tanaman dari Pulau Buton, Kabupaten Muna, Propinsi Sulawesi Tenggara. J Tanah Trop. 14:65-70.

Ramos-Morales E, Sanz-Sampelayo MR, Molina-Alcaide E. 2010. Nutritive evaluation of legume seeds for ruminant feeding. J Anim Physiol Anim Nutr (Berl). 94:55-64.

Ratnawaty S, Fernandes PTH. 2009. Perbaiakan kualitas pakan sapi melalui introduksi leguminosa herba dalam menunjang program kecukupan daging nasional di Kabupaten Timor Tengah Selatan. Prosiding Seminar Nasional Teknologi Peternakan dan Veteriner. Bogor (Indones): Pusat Penelitian dan Pengembangan Peternakan. p. 107-112.

Samedani B, Juraimi AS, Abdullah SAS, Rafii MY, Rahim AA, Anwar MP. 2014. Effect of cover crops on weed community and oil palm yield. Int J Agric Biol. 16:2331 .
Saraswati R, Husen E, Simanungkalit RD. 2007. Metode analisis biologi tanah. Bogor (Indones) Balai Penelitian Bioteknologi Tanaman Pangan.

Saraswati R, Hastuti RD, Sunarlin N, Hutamu. 1996. Penggunaan Rhizoplus Generasi 1 untuk meningkatkan Produksi Tanaman Kedelai. Bogor (Indones) Balai Penelitian Bioteknologi Tanaman Pangan.

SAS Institute Inc. 2009. SAS/STAT 9.2 User's Guide. User's Guide. Cary, NC (USA): SAS Inst Inc.

Van Saun RJ, Herdt T. 2013. Nutritional Assessment. In: Llama Alpaca Care Med Surgery, Reprod Nutr Herd Heal First Ed. p. 100-123.

Schipanski ME, Barbercheck M, Douglas MR, Finney DM, Haider K, Kaye JP, Kemanian AR, Mortensen DA, Ryan MR, Tooker J, White C. 2014. A framework for evaluating ecosystem services provided by cover crops in agroecosystems. Agric Syst. 125:12-22.

Shehu Y, Alhassan WS, Pal UR, Phillips CJC. 2001. Yield and chemical composition responses of Lablab purpureus to nitrogen, phosphorus and potassium fertilisers. Trop Grassl. 35:180-185.

Singh H, Reddy MS. 2011. Effect of inoculation with phosphate solubilizing fungus on growth and nutrient uptake of wheat and maize plants fertilized with rock phosphate in alkaline soils. Eur J Soil Biol. 47:30-34.

Van Soest PJ, Robertson JB, Lewis BA. 1991. Methods for dietary fiber, neutral detergent fiber, and nonstarch polysaccharides in relation to animal nutrition. J Dairy Sci. 74:3583-3597.

Somasegaran P, Hoben HJ. 1985. Methods in legumerhizobium technology. Trop Agric. p. 1-510.

Sopandie D, Chozin MA, Tjitrosemito S, Sahardi. 2003. Keefektifan uji cepat ruang gelap untuk seleksi ketenggangan terhadap naungan pada padi Gogo. Hayati. 10:91-95.

Suganda H, Rachman A, Sutono S. 2006. Petunjuk pengambilan contoh tanah. In: Sifat Fisik Tanah dan Metode Analisis. p. 3-24.

Suganya G, Sampath Kumar P, Dheepa B, Sivakumar R. 2014. In vitro antidiabetic, antioxidant and antiinflammatory activity of Clitoria ternatea L. Int J Pharm Pharm Sci. 6:342-347.

Tarigan A, Abdullah L, Ginting SP, Permana IG. 2010. Produksi dan komposisi kimia serta kecernaan invitro Indigofera sp pada interval dan tinggi pemotongan berbeda. JITV. 15:188-195.

Armiadi. 2009. Penambatan nitrogen secara biologis pada tanaman leguminosa. Wartazoa. 19:23-30.

Thang CM, Ledin I, Bertilsson J. 2009. Effect of feeding cassava and/or Stylosanthes foliage on the performance of crossbred growing cattle. Trop Anim Health Prod. 42:1-11. 
Valbuena D, Erenstein O, Homann-Kee Tui S, Abdoulaye T, Claessens L, Duncan AJ, G??rard B, Rufino MC, Teufel N, van Rooyen A, van Wijk MT. 2012. Conservation Agriculture in mixed crop-livestock systems: Scoping crop residue trade-offs in Sub-Saharan Africa and South Asia. F Crop Res. 132:175-184.

Weng B, Lei J, Jiang Z, Zhong Z, Xu G, Ye J. 2013. Substituting wheat bran with Chamaecrista rotundifolia hay powder in the substrate of tricholoma lobayense culture: Substrate weight loss dynamics and mass transformation ratios. Sci Hortic. 155:105-110.
Widawati S. 2006. Augmentation of potential phosphate solubilizing bacteria (PSB) stimulate growth of green mustard (Brasica caventis Oed.) in marginal soil. Biodiversitas, J Biol Divers. 7:10-14.

Zhou X, Chen C, Wu H, Xu Z. 2012. Dynamics of soil extractable carbon and nitrogen under different cover crop residues. J Soils Sediments. 12:844-853.

Zingare ML, Zingare PL, Dubey AK, Ansari MA. 2013. Clitoria ternatea (APARAJITA): A Review of the antioxidant, antidiabetic and hepatoprotective potentials. Int J Pharm Biol Sci. 3:203-213. 